二報 文二

\title{
サケ鼻軟骨熱水抽出物の経口㩒取による日焼け抑制効果 一無作為化二重盲検プラセボ対照並行群間比較試験一
}

\author{
(2015 年 9 月 25 日受付；2016年 1 月 7 日採択)
}

後藤昌史 $^{1, *}$ ，末川 裕 ${ }^{1}$ ，花田友香子 ${ }^{1}$ ，柿崎育子 ${ }^{2}$, 山本和司 ${ }^{1}$, 加藤陽治 ${ }^{3}$

1 サンスター株式会社新規素材活用事業開発プロジェクト (569-1044 大阪府高槻市上土室 5-30-1) 2 弘前大学大学院医学研究科附属高度先進医学研究センター糖鎖工学講座 (036-8562 青森県弘前市在府町 5) 3弘前大学教育学部食物学研究室 (036-8560 青森県弘前市文京町 1)

\section{The Suntan Suppressive Effect by Oral Ingestion of Hot Water Extract from Salmon Nasal Cartilage: A Randomized, Double-blind, Placebo-controlled Parallel-group Comparative Study}

Masashi Goto, ${ }^{1, *}$ Yutaka Suekawa, ${ }^{1}$ Yukako Hanada, ${ }^{1}$ Ikuko Kakizaki, ${ }^{2}$ Kazushi Yamamoto ${ }^{1}$ and Yoji Kato ${ }^{3}$

\begin{abstract}
${ }^{1}$ New Material Business Development, Sunstar Inc. (5-30-1 Kamihamuro, Takatsuki, Osaka 569-1044, Japan) ${ }^{2}$ Department of Glycotechnology, Center for Advanced Medical Research, Hirosaki University Graduate School of Medicine (5 Zaifu-cho, Hirosaki 036-8562, Japan)

${ }^{3}$ Laboratory of Food Science, Faculty of Education, Hirosaki University (1 Bunkyo-cho, Hirosaki, Aomori 036-8560, Japan)
\end{abstract}

\begin{abstract}
要旨：サケ鼻軟骨 (Salmon Nasal Cartilage) (以下 SNC とする) 熱水抽出物の摂取による日焼け抑制効果を, ヒト臨床試験により検証した. 27 歳から 44 歳の健康な成人女性を対象とし, SNC 熱水抽出物 $400 \mathrm{mg} / \mathrm{day}$, $\mathrm{SNC}$ 熱水抽出物 $200 \mathrm{mg} / \mathrm{day}$ またはプラセボを 8 週間連続摂取させ, 試験品摂取前 $(0 \mathrm{w})$, 摂取 4 週間後 (4 w), 摂取 8 週間後 $(8 \mathrm{w})$ および摂取終了 8 週間後 $(16 \mathrm{w})$ の各時点において, 紫外線照射後の最小紅斑量 (Minimal Erythema Dose, MED), 最小黑化量 (Minimal Tanning Dose, MTD) を測定した，統計解析につい ては, 分散分析を行い, 有意差が認められたものについてさらに多重比較検定を行った，その結果，MED に执いて, SNC 熱水抽出物 $400 \mathrm{mg} / \mathrm{day}$ 摂取群は, $0 \mathrm{w}$ から $16 \mathrm{w}$ への経時的な上昇傾向が認められたが, プ ラセボ摂取群との群間比較での有意差は認められなかった。一方 MTDに拮いて, SNC 熱水抽出物 $400 \mathrm{mg} /$ day 摂取群は, プラセボ摂取群との群間比較において, $8 \mathrm{w}$ 時点で有意に高く $(p=0.035), \quad 16 \mathrm{w}$ 時点で高い 傾向 $(p=0.077)$ であった. 以上より, SNC 熱水抽出物を 1 日当り $400 \mathrm{mg}$ ( SNC 熱水抽出プロテオグリカ ンとして $169 \mathrm{mg}) ， 8$ 週間摂取することで，紫外線によって皮膚が黒くなる日焼けを抑制し，紫外線による 皮膚ダメージを軽減させる効果があることが示唆された。
\end{abstract}

キーワード：サケ鼻軟骨，熱水抽出物，プロテオグリカン，紫外線，日焼け

現在の高齢化社会に抒いて, 人々が長年にわたり充実し た生活を送るためには，外面の若さを保つこと，すなわち 皮膚老化を防ぐことが QOL (Quality of Life) の観点で重要 である，特に，シミやシワなどの皮膚老化は，加齢による 老化と共に紫外線による光老化が大きく影響する1). 皮膚 が一定量以上の紫外線照射を受けると, 過㮃に発生した活 性酸素により炎症が起こり紅斑が発生し2,3，引き続きメラ 二ン新生による遅延型黒化 (以下黒化と略す) が生じる ${ }^{4,5}$. このような紫外線曝露が累積されることで, 表皮の肥厚や バリア機能の低下による乾燥肌が誘発され ${ }^{(-8)}$, さらには炎
症による皮膚ダメージが蓄積し，シミやシワなどの光老化 が誘発される ${ }^{9-13)}$. 近年, フロンガスなどによる成層圈才 ゾン層の破壊進行に伴い，地上に到達する紫外線量の増加 が報告されて㧍り ${ }^{14)}$ ，今後ますます，紫外線に対する防御 を意識することが必要である，そこで，日焼けを防ぎ皮膚 の光老化を予防するためには, 日傘や日焼け止めクリーム などの紫外線防御が必要であるが，それと共に，皮膚自体 の紫外線からの防御力を高め, 日焼けしにくい肌になるこ とが本質的に重要である.

プロテオグリカンは，コアタンパク質を軸に，1本ある 
いは複数のコンドロイチン硫酸などの糖鎖が共有結合した 糖タンパク質の一種であり, コラーゲンやヒアルロン酸に 並ぶ軟骨や皮膚の主要成分である ${ }^{15,16}$. プロテオグリカン は，糖鎖部分およびコアタンパク質部分が協調して機能 し，多様な生理活性を発揮するものと考えられている ${ }^{17}$. 組織中の存在形態としては, 多数のプロテオグリカンがヒ アルロン酸の軸に非共有結合した巨大な凝集体を形成 し 18-20), さらにヒアルロン酸-プロテオグリカン凝集体はコ ラーゲンとのネットワーク構造を形成している。それらは 保水能力を維持し, 軟骨や皮膚などの組織における物理的 刺激を和らげるためのクッションとしての役割を果たして いる ${ }^{21-23)}$. 柿崎らは, nano-LC/MS/MS 解析により, サケ 鼻軟骨 (Salmon Nasal Cartilage) (以下 SNC とする) プロテ オグリカンの大部分がアグリカンと呼ばれるプロテオグリ カンであり，そのコアタンパクは，哺乳動物と同様に機能 的なドメインを全て有することを明らかにした ${ }^{24)}$.また, 生化学的な分析と原子間力顕微鏡 (AFM) による観察によ り, SNC プロテオグリカンの全体像と構造的特徴を明ら かにした上で，ウシ気管支軟骨プロテオグリカンとの構造 の違いを示し，これまでの量産技術である酢酸抽出による SNC プロテオグリカンは, 低分子化していることを示し た ${ }^{25)}$. 三浦らは，SNC 粉末から，異なる溶媒で抽出したプ ロテオグリカンの性質を比較した結果, 酢酸, リンゴ酸や クエン酸などの有機酸や水酸化ナトリウムで抽出されたプ ロテオグリカンの分子量は低分子化され，水抽出で得られ たプロテオグリカンについては分子量が高く, 天然型に近 い状態で抽出されていることを示唆した ${ }^{20)}$.このように, 由来動物や抽出溶媒の違いにより得られるプロテオグリカ ンの構造は異なる。我々は, 紫外線照射誘導皮膚老化モデ ルマウスを用いて, 天然型に近い状態のプロテオグリカン を豊富に含む SNC 脱脂粉末 ${ }^{27,28)}$ の水抽出物の経口投与実験 を行った結果, コンドロイチン硫酸と比べて, 皮膚の紅斑 発生，表皮バリアの崩壊および皮膚肥厚などの光老化を抑 制する効果が高いことを見出した ${ }^{29}$.

我々は，この天然型に近い状態の SNC プロテオグリカ ンを食品などへ幅広く応用していくため, SNCの熱水抽 出法を開発し, $\mathrm{SNC}$ 脱脂粉末の水抽出液と同様に, 光老 化抑制効果が高い天然型に近い状態のプロテオグリカンを 豊富に含む SNC 熱水抽出物の原料化を達成した (原料 名：ヒアルコ $\left.\mathrm{PG}^{\circledR}\right)^{30)}$. 熱水抽出法に必要な溶媒は水のみ であり，プロセスが単純であるため，酸やアルカリを使用 する従来の方法と比較して低コスト製造が実現でき，有効 量を配合した食品やサプリメントなど幅広い活用が期待で きる，我々は，紫外線による肌ダメージを軽減し光老化を 抑制する機能を有する食品への応用検討として，ヒトでの $\mathrm{SNC}$ 熱水抽出物摂取による日焼け抑制効果を検証するこ ととした

\section{1. 実 験 方 法}

\section{1) 倫理的事項}

本試験は世界医師会によるへルシンキ宣言に示された倫 理規範を踏まえ, 被験者の人権保護に配慮し, 疫学研究に 関する倫理指針 (文部科学省, 厚生労働省) に従い, 医療 法人健昌会福島健康管理センター (大阪) の倫理審査委員 会において審査，承認された後に実施した (承認日：2012 年 9 月 13 日). 被験者が試験に参加する前に，あらかじめ 倫理審査委員会で承認の得られた説明文書を被験者に渡 し，本試験の目的や内容等について十分に説明を行い，被 験者が内容を十分に理解し, 納得したことを確認した上 で，本試験への参加について自由意思による同意を被験者 本人より文書で得た。

\section{2) 試験デザイン}

試験デザインは, 無作為化二重盲検プラセボ対照並行群 間比較試験とした。

\section{3) 試験実施期間}

2012 年 10 月 1 日 2013 年 2 月 11 日

\section{4) 被 験 者}

試験の被験者は，年齢が 25 歳以上 45 歳未満で, Fitz-

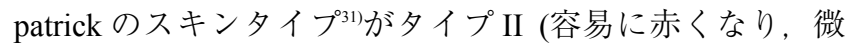
かに黒くなる) または夕イプIII (赤くなった後, いつも黒 くなる) に該当すると自己判断した健常な日本人女性を 2 カ所のモニターバンクの登録者より募集し，試験の目的や 内容等を説明し，文書にて同意を取得した (81 名). 同意 した被験者に, 背景情報として, 疾病履歴, アレルギーの 有無, 皮膚の状態, 美容医療やエステ等の実施状況, 医薬 品や健康食品の摂取状況などについてアンケートを行い, 被験者候補であることを確認し，スクリーニング検査とし て日常生活で太陽光への暴露が少ないと考えられる背部を 評価部位として，被験者候補の背中に紫外線を照射し最小 紅斑量 (Minimal Erythema Dose, MED) と最小黑化量 (Minimal Tanning Dose, MTD) を測定した. MEDは, 照 射 1 日後に境界のはっきりしたかすかな紅斑を起こすのに 必要な最小の紫外線量であり, MTD は, 照射 7 日後に肉 眼で認められる最小の色素沈着を引き起こすのに必要な紫 外線量である ${ }^{32}$. 測定結果を集計し, MED と MTD が近似 しかつ MED およびMTDの值が被験者候補全体の中央值 に近いことを基準に 44 名を選択し，適格な被験者として 試験に登録した。これら被験者を乱数を用いて三群 (SNC 熱水抽出物 $400 \mathrm{mg} /$ day 摂取群 15 名, SNC 熱水抽出物 200 $\mathrm{mg} /$ day 摂取群 14 名, プラセボ摂取群 15 名) の割付表を 作成し割付けた。表 1 に, 割付けられた被験者の年齢, MED，MTDそれぞれの測定值およびMTD/MED 比の平 均值 \pm 標準偏差を示す。それぞれの項目において, 三群 
表 1. 割付時の被験者の年齢と MED, MTD, MTD/MED 比 (平均值 \pm 標準偏差)

\begin{tabular}{lccccc}
\hline & $n$ 数 & 年齢 (歳) & MED $\left(\mathrm{mJ} / \mathrm{cm}^{2}\right)$ & $\mathrm{MTD}\left(\mathrm{mJ} / \mathrm{cm}^{2}\right)$ & $\mathrm{MTD} / \mathrm{MED}$ 比 \\
\hline SNC 熱水抽出物 $400 \mathrm{mg} /$ day 摂取群 & 15 & $37.3 \pm 4.4$ & $22.3 \pm 4.1$ & $28.2 \pm 5.6$ & $1.27 \pm 0.19$ \\
SNC 熱水抽出物 $200 \mathrm{mg} /$ day 摂取群 & 14 & $38.6 \pm 4.0$ & $22.6 \pm 4.3$ & $28.4 \pm 6.5$ & $1.27 \pm 0.29$ \\
プラセボ摂取群 & 15 & $38.0 \pm 5.2$ & $22.4 \pm 4.1$ & $28.2 \pm 5.7$ & $1.26 \pm 0.17$ \\
\hline
\end{tabular}

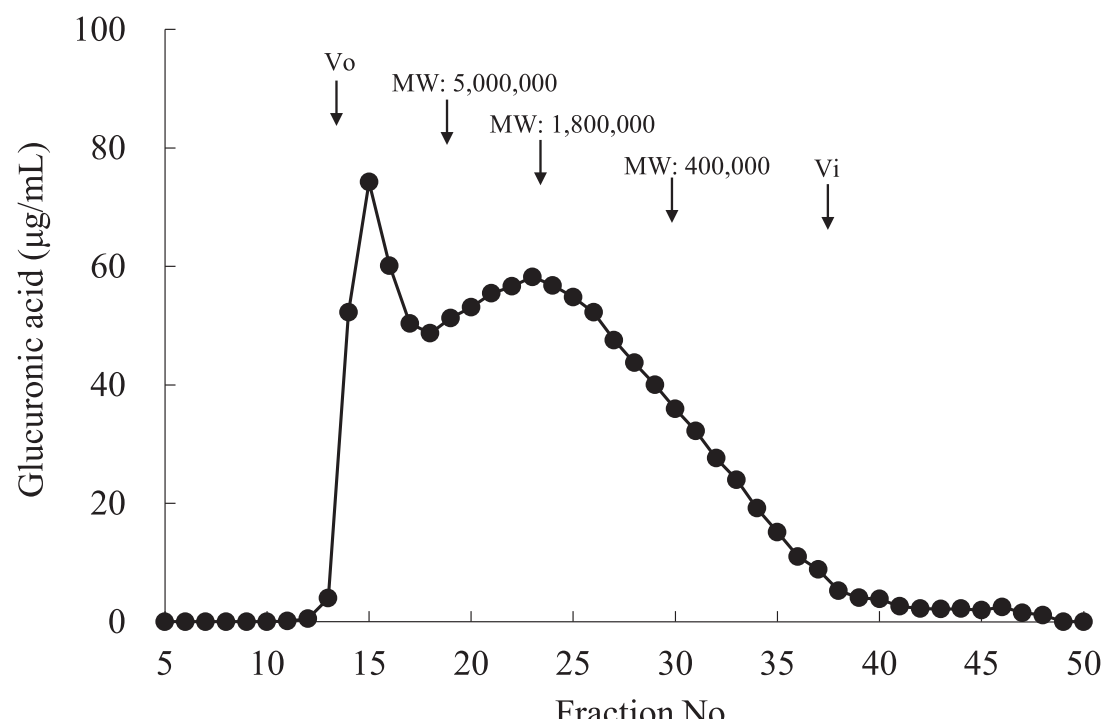

図 1. SNC 熱水抽出物の CL-2B ゲル濾過カラムクロマトグラフィー

グルクロン酸の $1.15 \mathrm{mg}$ に相当する $\mathrm{SNC}$ 熱水抽出物を $0.2 \mathrm{M}$ 塩化ナトリウムを 含む $0.1 \mathrm{M}$ リン酸緩衝液 $(\mathrm{pH}=7.1$ ) (以下, $0.1 \mathrm{M}$ リン酸緩衝液) $1 \mathrm{~mL}$ に溶解し, $0.1 \mathrm{M}$ リン酸緩衝液で平衡化した Sepharose CL-2B ゲルろ過カラム $(\phi 1.0 \times 50$ $\mathrm{cm} ; \mathrm{GE} ヘ ル$ スケアジャパン(株)，東京) に供した。その後同じ緩衝液で溶出し，1 $\mathrm{mL}$ ずつ画分を収集し，カルバゾール硫酸法により各画分のグルクロン酸濃度を測 定した ${ }^{34)}$. 分子量マーカーとして，3つの分子量違いデキストランをそれぞれ 0.5 $\mathrm{mg}$ を上記と同じ操作で溶出し, $1 \mathrm{~mL}$ ずつ画分を収集し, フェノール硫酸法によ り糖量を測定し ${ }^{34)}, 3$ 点検量線を作成し, 分子量 500 万, 180 万, 40 万の溶出位置 を求めた。 分子量マーカー： dextran from Leuconostoc mesenteroides (average MW 5,000,000-40,000,000; Sigma-Aldrich Corp., St. Louis, MO), dextran standard 1,400,000 from L. mesenteroides (MW 1,400,000; Sigma-Aldrich Corp.) および dextran standard 410,000 from L. mesenteroides (MW 410,000; Sigma-Aldrich Corp.).

それぞれの標準偏差から考慮し，三群間に解析に影響する 程度の偏りはないことを確認した。

\section{5) SNC 熱水抽出物の調製}

サケの頭部から取り出した鼻軟骨は, 青森県内の水産加 工業者より入手した。 サイレントカッターNHY-20 (株長 沼製作所, 東京)により細断化した鼻軟骨 $(63.1 \mathrm{~kg})$ を流 水により水洗した後, 熱水 $\left(160 \mathrm{~L}, 90^{\circ} \mathrm{C}\right.$ 以上) 中に投入 し攪拌した，鼻軟骨が全体的に溶解したことを確認できた 段階で加熱を止め, 濾過により不溶成分を取り除き, 遠心 分離により脂質を取り除いた。 その後凍結乾燥により, $\mathrm{SNC}$ 熱水抽出物 $(3.9 \mathrm{~kg})$ を得た。本試験に使用する $\mathrm{SNC}$ 熱水抽出物のプロテオグリカン含有量は, カルバゾール硫 酸法 ${ }^{33}$ によりグルクロン酸濃度を決定し, プロテオグリカ ンの分子量中に占めるグルクロン酸の分子量の比率 ${ }^{34}$ から 計算した結果， $42.2 \%$ であった。また，前報 試験に使用する $\mathrm{SNC}$ 熱水抽出物をゲル濾過カラムクロマ トグラフィーに供し, 分子量分布を測定した結果, 天然型 に近い状態のプロテオグリカン (分子量約 180 万および分
子量 500 万以上のプロテオグリカン) を豊富に含むことが 示された (図 1).

\section{6) 試験品の概要}

試験品は, $\mathrm{SNC}$ 熱水抽出物が配合された $2 つ の$ 被験品 とプラセボの計 3 つした，試験品の原材料組成㧍よびプ ロテオグリカン含有量と栄養成分を表 2 に示す，被験品 1 は, SNC 熱水抽出物 $400 \mathrm{mg} /$ day, 被験品 2 は, SNC 熱水 抽出物 $200 \mathrm{mg} / \mathrm{day}$ に設定した. 結晶セルロースは, セ才 ラス ${ }^{\circledR} \mathrm{ST}-02$ (旭化成ケミカルズ侏)，東京）を使用した，そ れぞれの試験品は, 1 日分の $400 \mathrm{mg}$ をブタ由来ゼラチン カプセル (2 号白色, カプスゲル・ジャパン(株), 神奈川) 5 個に充填し, チャック付きポリエチレン袋に 1 日分として 個別収納した。

\section{7) 試験品の使用方法，使用量および使用期間}

試験品は，1 日に 1 回朝食時に， 5 カプセル $(80 \mathrm{mg} \times 5)$ を，コップ 1 杯程度の水または微温湯とともに摂取する. 試験品の摂取期間は 8 週間とした. 
表 2. 試験品の組成等

被験品 1

(SNC 熱水抽出物 $400 \mathrm{mg} /$ day)
被験品 2

(SNC 熱水抽出物 $200 \mathrm{mg} /$ day)

$400 \quad 200 \quad-$

$<$ 原材料>
SNC 熱水抽出物 $(\mathrm{mg})$

結晶セルロース $(\mathrm{mg})$

-

84

プロテオグリカン含有量 $(\mathrm{mg}) ※$

169

84

0.7

104

2.8

208

5.6

122

4.6

252

2.3

ナトリウム $(\mathrm{mg})$

0

プラセボ

\author{
0 \\ 0.4 \\ 0.1 未満 \\ 381 \\ 0.1 末満
}

\section{8) 紫外線照射機器と紫外線照射方法}

紫外線照射機器および紫外線照射方法は, 日本化粧品工 業連合会 SPF (Sun Protection Factor) 測定法基準 ${ }^{35} に$ 準じ た。照射装置はSPF 測定に用いられる紫外線照射装置 (MeV-SPF6P，(株ワイ・イー・ブイ，大阪）を使用し，光 源は，紫外線領域に異常な放射ピークを持たず連続したス ペクトルを放射するキセノンランプ (L9289-01, 浜松ホト ニクス(侏，静岡）を使用し，照射スペクトルは，MeV-SPF 6Pのフィルター切り替えにより $290 \sim 400 \mathrm{~nm}$ とした. 1 照射野は $0.5 \mathrm{~cm}^{2}$ ( $\left.\phi 8 \mathrm{~mm}\right)$ で, 一度の照射で同時に 6 力所 (3×2 列) 照射した，紫外線照射量の測定は，PMA2100 (Solar Light Co. Inc., Glenside, USA) (UV センサー, PMA 2103)を使用した。

\section{9) 試験のスケジュール}

試験スケジュールを表 3 に示す。被験者に対して, 摂取 前 (以下 $0 \mathrm{w}$ とする) 検查第 1 日目を行った。まず被験者 の背部を蒸留水で湿らせたコットンで洗拭した後, 室温を $20 \sim 25^{\circ} \mathrm{C}$ に調節した室内にて 20 分間以上安静待機し, 馴 化した，馴化後，被験者の背部の 6 力所 (1 照射野は 0.5 $\left.\mathrm{cm}^{2}(\phi 8 \mathrm{~mm})\right)$ に, 予測 MED 㧍よび予測 MTD (スクリー ニング検査時の MED および MTD) の両方が中心寄りにな るように公比 1.1 で 6 段階の線量の紫外線を照射し, 翌日 $(0 \mathrm{w}$ 検查第 2 日目) に MED の判定, 7 日後 $(0 \mathrm{w}$ 検查第 8
日目)にMTDの判定を実施した。 $0 \mathrm{w}$ 検查第 8 日目終了 後, 試験品を被験者へ手渡し, 翌日の朝 $(0 \mathrm{w}$ 検査第 9 日 目) から摂取を開始させた。試験品の摂取期間は 8 週間と し, 摂取 4 週間後 (以下 $4 \mathrm{w}$ とする), 摂取 8 週間後 (以下 $8 \mathrm{w}$ とする), 摂取終了 8 週間後 (以下 $16 \mathrm{w}$ とする) に試 験実施施設に来場して，0 $\mathrm{w}$ 検査と同様に，それぞれ第 1 日目に予測 MED および予測 MTD (前検查時の MED およ びMTD) の両方が中心寄りになるように公比 1.1 で 6 段 階の線量の紫外線を照射し, 第 2 日目にMEDの判定, 第 8 日目に MTDの判定を実施した。検査ごとの紫外線照射 部位は, 以前の検査時に照射した部位を避け, 重ならない よう照射した。毎回の検査は，お抒むね同じ時間帯に行っ た。また，被験者には摂取期間を通して試験品の摂取状 況, 体調の変化や医薬品やサプリメントの摂取状況などを 日誌に記録させ，各検査日に記入済みの日誌を回収した。 な㧍, 医療法人健昌会福島健康管理センターの近藤澄夫医 師を試験責任医師とし, 被験者の募集と選定, 割付, 紫外 線照射およびMED，MTD の評価およびデー夕解析の一連 の試験は，DRC (侏) (大阪)にて実施した。

\section{0) 被験者の制限事項および禁止事項}

被験者に対して試験期間中は試験参加前の通常の生活を 送るとともに，以下の制限拉よび禁止事項を守るように指 導した。

表 3. 試験スケジュール

\begin{tabular}{|c|c|c|c|c|c|c|c|c|c|c|c|c|c|}
\hline & \multicolumn{3}{|c|}{ 摂取前 } & \multicolumn{7}{|c|}{ 摂取期間 } & \multirow{2}{*}{\multicolumn{3}{|c|}{$\begin{array}{c}\text { 後観察期間 } \\
16 \mathrm{w} \text { 検査 }\end{array}$}} \\
\hline & \multicolumn{4}{|c|}{$0 \mathrm{w}$ 検査 } & \multicolumn{3}{|c|}{$4 \mathrm{w}$ 検査 } & \multicolumn{3}{|c|}{$8 \mathrm{w}$ 検査 } & & & \\
\hline & 1 日目 & 2 日目 & 8 日目 & 9 日目 & 1 日目 & 2 日目 & 8 日目 & 1 日目 & 2 日目 & 8 日目 & 1 日目 & 2 日目 & 8 日目 \\
\hline 来場 & 0 & 0 & 0 & & 0 & 0 & 0 & 0 & 0 & 0 & 0 & 0 & 0 \\
\hline 紫外線照射 & 0 & & & & 0 & & & 0 & & & 0 & & \\
\hline MED 判定 & & 0 & & & & 0 & & & 0 & & & 0 & \\
\hline MTD 判定 & & & 0 & & & & 0 & & & 0 & & & 0 \\
\hline 試験品の摂取 & & & & 4 & & & & & & $\longrightarrow$ & & & \\
\hline 日誌の記録 & 4 & & & & & & & & & $\rightarrow$ & & & \\
\hline
\end{tabular}


（1）試験期間中は，できるだけ規則的な生活を心がけ， 日常範囲を大きく逸脱する過度な運動, 睡眠不足, ダイエット拉よび暴领暴食を避ける。 (制限事項)

（2）試験期間中は，日常生活を越えて過度に紫外線を 浴びないように注意する。(制限事項)

（3）試験期間中は，やむを得ない場合を除き，医薬品 を使用しない，医薬品を使用する場合は日誌に医 薬品名と使用量を記録する。( (制限事項)

（4）試験期間中は, 美容医療や特別なスキンケア (エス テなど)を受けることを禁止する. (禁止事項)

（5）評価部位に対して，本試験で検討する有効性と同 様もしくは関連する効果効能 (美白効果) を標榜あ るいは強調した健康食品やサプリメント，スキン ケア製品や化粧品，医薬部外品などの使用を禁止 する (禁止事項)

（6）検查日前 3 日間は夜更かし, 徹夜および激しい運 動 (息が上がるようなランニング, 水泳, 登山な ど)を禁止する. (禁止事項)

（7）検査当日は, 起床後から検査終了まで入浴 (シャ ワーを含む) を禁止する。(禁止事項)

\section{1) 解析対象者}

有効性の解析対象者は, 所定の試験スケジュールと検査 内容を完了した被験者のうち, 以下の解析対象不採用基準 に該当する被験者を除いて最終解析者とした。

〈解析対象不採用基準〉

(1) 試験品の摂取回数が極端に少ない人.

（2）各種記録の欠損, 制限事項違反など検査結果の信 頼性を損なう行為が顕著にみられる人.

（3）除外基準に該当していたことが試験組入れ後に判 明した人。

(4) $0 \mathrm{w}, 4 \mathrm{w}, 8 \mathrm{w}$ のいずれかの検査において, MED あるいは MTD の判定不能が 1 回以上あった人.

（5）その他解析から除外することが適当と考えられる 明らかな理由がある人

なお，(4) の判定不能とは, MED 判定時に, 6 力所の照 射部位全てが一様に赤くなるあるいは 6 力所全てで赤くな らない状態，MTD 判定時も同様に，6力所全てが一様に 黒くなるあるいは 6 力所全てで黒くならない状態を示す. 背中の地肌の色にムラがある人は，測定ブレが大きくな り, 判定不能となることがあると予想されたため, 測定不 能が生じた被験者は，解析対象から外すこととした，

\section{2) 解析方法}

MED 值, MTD 值について, 各検査時点の測定値の平均 值と標準偏差㧍よび, $0 \mathrm{w}$ に対する各検查時点 $(4 \mathrm{w}, 8 \mathrm{w}$, $16 \mathrm{w})$ の増減率 (以下増減率と略す) の平均値と標準偏差 を算出した。統計学的検定は評価項目ごとに, 測定值およ び増減率について試験品要因 (以下群間とする) と時間要 因 (以下群内とする) 2 要因とした反復測定 2 元配置分 散分析を行い, 有意差が認められたものについて，さらに Dunnett の多重比較検定を行った。なお，増減率について は, $0 \mathrm{w}$ をベースラインに変換しているため, 検定は群間 比較のみ行った。解析ッールとして, JMP ${ }^{\circledR}$ ver.10 (SAS Institute Japan (侏) を使用し，有意水準は $5 \%$ 未満とした。

\section{2. 結果}

\section{1) 被験者の内訳}

スクリーニングを行った被験者候補から適格な被験者と して 44 名を選択し，試験品の摂取を開始させた，試験品 を摂取開始した 44 名全員が $8 \mathrm{w}$ 検査まで完了した，その うち, $0 \mathrm{w}, 4 \mathrm{w}, 8 \mathrm{w}$ のいずれかの検査期間 (紫外線照射 から MTD 判定までの 8 日間) 中に，風邪により体調が悪 化した 2 名及び頭痛により体調が悪化した 1 名, 計 3 名 (SNC 熱水抽出物 $400 \mathrm{mg} /$ day 摂取群 1 名, SNC 熱水抽出 物 $200 \mathrm{mg} /$ day 摂取群 1 名, プラセボ摂取群 1 名) は, MED およびMTDに影響を及ぼすと考えられる抗炎症作 用のある医薬品を使用していたため, 有効性解析から除外 した。さらに， $0 \mathrm{w} ， 4 \mathrm{w} ， 8 \mathrm{w}$ のいずれかの検查に抢い て，MED あるいは MTD の判定不能が 1 回以上あった 16 名 (SNC 熱水抽出物 $400 \mathrm{mg} / \mathrm{day}$ 摂取群 6 名, SNC 熱水抽 出物 $200 \mathrm{mg} / \mathrm{day}$ 摂取群 7 名, プラセボ摂取群 3 名) を有 効性解析から除外した。 また, 1 名 (SNC 熱水抽出物 200 $\mathrm{mg} / \mathrm{day}$ 摂取群) が自己都合により後観察期間である $16 \mathrm{w}$ 検査のみ欠席したが，解析対象不採用基準に該当しないた め, 当該時点のデー夕を欠損值として扱い, 解析対象者と した。したがって, 解析対象者は 25 名 (SNC 熱水抽出物 $400 \mathrm{mg} /$ day 群 8 名, SNC 熱水抽出物 $200 \mathrm{mg} /$ day 群 6 名, プラセボ群 11 名) であった。表 4 に, 最終解析者の年齢, $0 \mathrm{w}$ 検査時の MED, MTD それぞれの測定值および MTD/ MED 比の平均值士標準偏差を示す，それぞれの項目にお いて, 三群それぞれの標準偏差から考慮し, 三群間に解析 に影響する程度の偏りはないことを確認した。

表 4. 最終解析者の被験者の年齢と MED, MTD, MTD/MED 比 (平均值 \pm 標準偏差)

\begin{tabular}{lccccc}
\hline & $n$ 数 & 年齢 (歳) & MED $\left(\mathrm{mJ} / \mathrm{cm}^{2}\right)$ & $\mathrm{MTD}\left(\mathrm{mJ} / \mathrm{cm}^{2}\right)$ & $\mathrm{MTD} / \mathrm{MED}$ 比 \\
\hline SNC 熱水抽出物 $400 \mathrm{mg} /$ day 摂取群 & 8 & $36.9 \pm 4.0$ & $22.7 \pm 4.3$ & $29.7 \pm 7.8$ & $1.31 \pm 0.19$ \\
SNC 熱水抽出物 $200 \mathrm{mg} /$ day 摂取群 & 6 & $37.2 \pm 5.1$ & $25.4 \pm 6.1$ & $34.0 \pm 9.4$ & $1.34 \pm 0.21$ \\
プラセボ摂取群 & 11 & $37.5 \pm 5.4$ & $24.4 \pm 5.8$ & $30.0 \pm 5.4$ & $1.26 \pm 0.17$ \\
\hline
\end{tabular}

MED, MTD の数值は, $0 \mathrm{w}$ 検査時の測定值を示す. 
表 5. MED の測定值および $0 \mathrm{w}$ に対する増減率 (平均值 \pm 標準偏差)

\begin{tabular}{|c|c|c|c|c|c|c|c|}
\hline \multirow{2}{*}{ 摂取群 } & \multicolumn{4}{|c|}{ 測定值 $\left(\mathrm{mJ} / \mathrm{cm}^{2}\right)$} & \multicolumn{3}{|c|}{$0 \mathrm{w}$ に対する増減率 (\%) } \\
\hline & $0 \mathrm{w}$ & $4 \mathrm{w}$ & $8 \mathrm{w}$ & $16 \mathrm{w}$ & $4 \mathrm{w}$ & $8 \mathrm{w}$ & $16 \mathrm{w}$ \\
\hline $\mathrm{SNC}$ 熱水抽出物 $400 \mathrm{mg} / \mathrm{day}$ 摂取群 & $22.7 \pm 4.3$ & $27.7 \pm 8.7$ & $30.1 \pm 8.8$ & $31.9 \pm 8.6 \#$ & $20.6 \pm 20.0$ & $30.8 \pm 19.5$ & $39.3 \pm 22.2$ \\
\hline $\mathrm{SNC}$ 熱水抽出物 $200 \mathrm{mg} /$ day 摂取群 & $25.4 \pm 6.1$ & $27.9 \pm 6.6$ & $29.2 \pm 6.9$ & $30.9 \pm 7.4$ & $10.6 \pm 12.2$ & $16.0 \pm 15.7$ & $33.4 \pm 35.6$ \\
\hline プラセボ摂取群 & $24.4 \pm 5.8$ & $26.7 \pm 6.0$ & $28.1 \pm 6.8$ & $29.3 \pm 6.9$ & $10.3 \pm 11.3$ & $15.7 \pm 16.8$ & $20.5 \pm 13.4$ \\
\hline
\end{tabular}

\#, 群内 $(v s .0 \mathrm{w})$ での Dunnett test $(p<0.1)$; †, 群間 $(v s$. プラセボ $)$ での Dunnett test $(p<0.1)$; 群間 $(v s$. プラセボ $)$ での Dunnett test $(p<0.05)$.

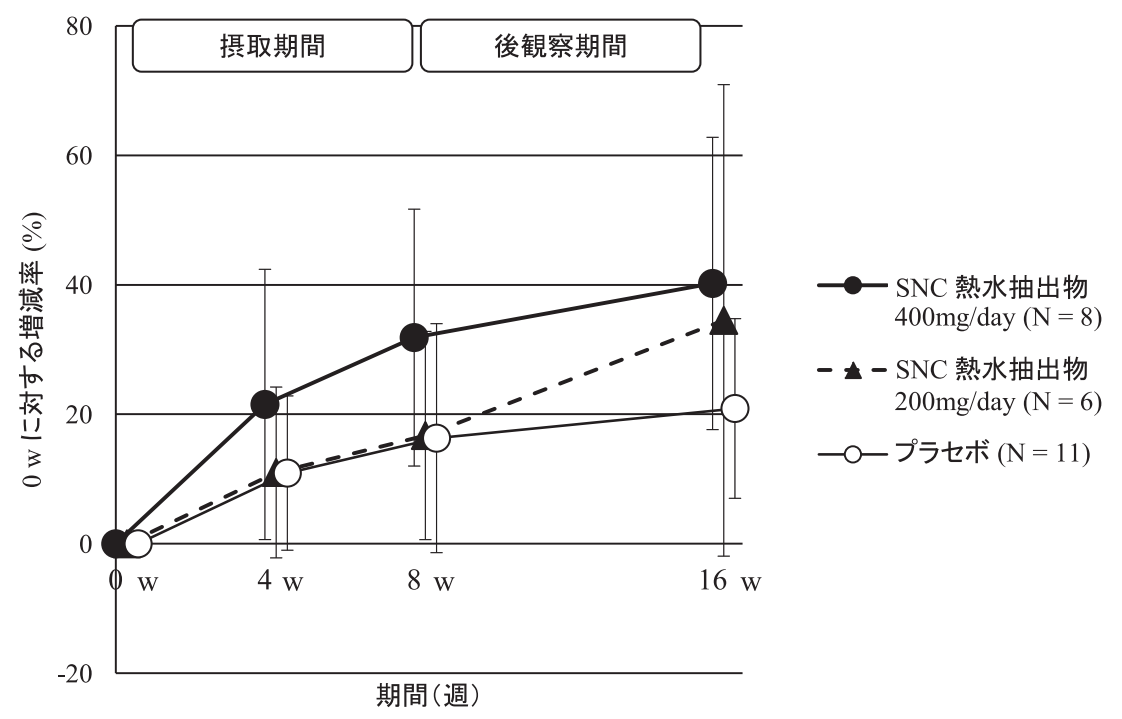

図 2. MED の $0 \mathrm{w}$ に対する増減率

†群間 (vs. プラセボ) での Dunnett test $(p<0.1)$, \$群間 (vs. プラセボ) での Dunnett test $(p<0.05)$.

\section{2) MED}

MED の測定值および増減率を表 5 に, 増減率のグラフ を図 2 に示す。また, 群間あるいは群内それぞれの多重比 較検定結果を表 5 および図 2 に示す.

測定值についての分散分析の結果，群内に有意差 $(p<$ 0.001) が認められ, 群間及び群間と群内の交互作用に有 意差は認められなかった。引き続き, 各群の時間要因につ いて Dunnettの多重比較検定を行った結果, いずれの群に も有意な差は認められなかったが, SNC 熱水抽出物 400 $\mathrm{mg} /$ day 摂取群において 0 w (22.7 \pm 4.3) から $16 \mathrm{w}(31.9 \pm$ 8.6) に上昇傾向 $(p=0.066)$ が認められた.

増減率についての分散分析の結果, 群間および群間・群 内の交互作用に有意差は認められなかった。 以上より, $\mathrm{SNC}$ 熱水抽出物 $400 \mathrm{mg} / \mathrm{day}$ 摂取群は, 経時での MEDの 上昇傾向は見られるが，プラセボ摂取群との有意な差は認
められなかった。

\section{3) MTD}

MTD の測定值および増減率を表 6 に, 増減率のグラフ を図 3 に示す。また，群間あるいは群内それぞれの多重比 較検定結果を表 6 および図 3 に示す.

測定值についての分散分析の結果，群内 $(p<0.001)$ お よび群間・群内の相互作用 $(p=0.011)$ に有意差が認めら れ，群間に有意差は認められなかった。しかしながら，各 群の群内について Dunnettの多重比較検定を行った結果, いずれの群も有意差は認められなかった。また，各検査時 点における群間についての Dunnett の多重比較検定を行っ た結果についても，いずれの検査時点においても有意差は 認められなかった。

増減率についての分散分析の結果, 群間 $(p=0.075)$ に

表 6. MTD の測定值および $0 \mathrm{w}$ に対する増減率 (平均值 \pm 標準偏差)

\begin{tabular}{|c|c|c|c|c|c|c|c|}
\hline \multirow{2}{*}{ 摂取群 } & \multicolumn{4}{|c|}{ 測定值 $\left(\mathrm{mJ} / \mathrm{cm}^{2}\right)$} & \multicolumn{3}{|c|}{$0 \mathrm{w}$ に対する増減率 (\%) } \\
\hline & $0 \mathrm{w}$ & $4 \mathrm{w}$ & $8 \mathrm{w}$ & $16 \mathrm{w}$ & $4 \mathrm{w}$ & $8 \mathrm{w}$ & $16 \mathrm{w}$ \\
\hline $\mathrm{SNC}$ 熱水抽出物 $400 \mathrm{mg} / \mathrm{day}$ 摂取群 & $29.7 \pm 7.8$ & $32.9 \pm 9.3$ & $34.7 \pm 8.7$ & $34.5 \pm 8.0$ & $10.5 \pm 9.9$ & $17.7 \pm 15.6$ \$ & $17.2 \pm 11.8 \dagger$ \\
\hline SNC 熱水抽出物 $200 \mathrm{mg} /$ day 摂取群 & $34.0 \pm 9.4$ & $34.6 \pm 9.7$ & $33.0 \pm 7.1$ & $34.4 \pm 7.3$ & $2.2 \pm 12.5$ & $-0.4 \pm 16.2$ & $10.8 \pm 14.2$ \\
\hline プラセボ摂取群 & $30.0 \pm 5.4$ & $32.3 \pm 7.1$ & $30.5 \pm 5.9$ & $31.4 \pm 5.7$ & $6.7 \pm 8.0$ & $1.6 \pm 10.0$ & $5.2 \pm 10.8$ \\
\hline
\end{tabular}

\# 群内 $(v s .0 \mathrm{w})$ での Dunnett test $(p<0.1)$; †群間 $(v s$. プラセボ $)$ での Dunnett test $(p<0.1)$; ：群間 $(v s$. プラセボ $)$ での Dunnett test $(p<0.05)$. 


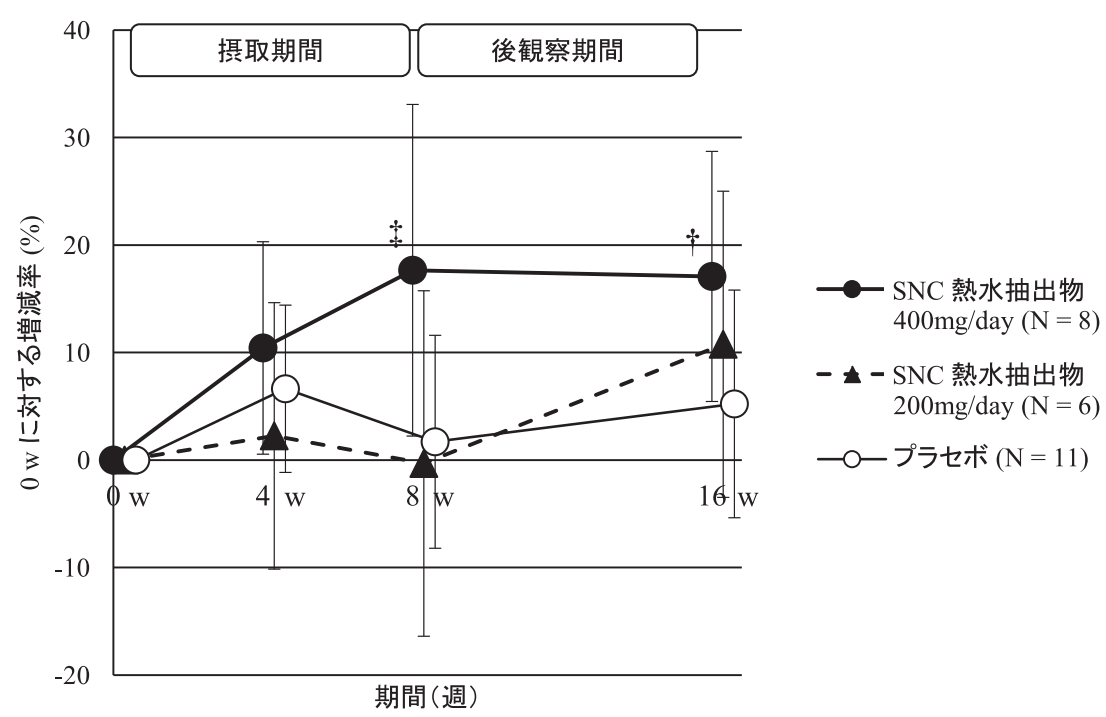

図 3. MTD の $0 \mathrm{w}$ に対する増減率

†群間 (vs. プラセボ) での Dunnett test $(p<0.1)$ ， 末群間 (vs. プラセボ) での Dunnett test $(p<0.05)$.

有意傾向が認められ, 群内・群間の相互作用 $(p=0.036)$ に有意差が認められた。引き続き，各検査時点における試 験品要因についてのDunnettの多重比較検定を行った結 果, SNC 熱水抽出物 $400 \mathrm{mg} / \mathrm{day}$ 摂取群は, プラセボ摂取 群との群間比較において, $8 \mathrm{w}$ 時点で有意に高く $(p=$ 0.035), $16 \mathrm{w}$ 時点で高い傾向 $(p=0.077)$ であった. SNC 熱水抽出物 $400 \mathrm{mg} /$ day 8 週間摂取することにより, 紫 外線照射による皮膚の黒化は抑制されることが示され，摂 取を中止した後も効果が持続する傾向が認められた。

\section{4) 有害 事 象}

有害事象の評価対象者は, 被験者全員 (44 名) とした. 8 週間の摂取期間中, 被験者の自己申告, 日誌への記載, 試験時の問診・観察などにより確認された有害事象を集計 し, 何らかの有害事象の発生率は, SNC 熱水抽出物 400 $\mathrm{mg} /$ day 摂取群 $40 \%$, SNC 熱水抽出物 $200 \mathrm{mg} /$ day 摂取群 $50 \%$, プラセボ摂取群 47\% であった。 有害事象の内容と して, 風邪が最も多く, このほか頭痛, 喉の痛み, 胃腸 炎, 胃もたれ, 関節痛, 腰痛, 貧血などであった。 これら すべての有害事象は, 試験責任医師により試験品とは関連 しないと判定された。このことより， SNC 熱水抽出物の 摂取による安全性上の問題は認められなかった。

\section{3. 考察}

$\mathrm{SNC}$ 熱水抽出物の摂取による紫外線照射による日焼け の抑制効果を確認するため, 年歯令が 25 歳以上 45 歳未満の 健常な女性を募集し，普段紫外線の影響が少ない背中を照 射部位として, SNC 熱水抽出物 $(400 \mathrm{mg} / \mathrm{day}, 200 \mathrm{mg}$ ) day) あるいはプラセボを摂取してもらい, MEDおよび MTD 測定を実施した。スクリーニング検査により，MED とMTDが近似しかつ MED およびMTDの值が被験者候 補全体の中央值に近いことを基準に被験者として三群合わ
せて 44 名で実施した。 しかし，0w，4 w，8wの摂取期 間での検査において，MED あるいはMTDの判定ができ ない場合があった解析除外者が多く，最終解析者として 25 名となった，検査での背中への紫外線照射の部位は重 ならないよう照射部位を変えて実施したため，照射範囲は 背中の広範囲となるが，背中の測定部位ごとの地肌の色が 異なる人の場合，想定された 6 段階の照射量範囲からずれ て測定不能となる可能性が高かったものと推察された。ま た，地肌の色ムラ以外に，試験開始 2 力月以前ではある が，夏期の背中の日焼けが十分に収束せず，判定に悪影響 を及ぼした可能性がある。

解析の結果, $\mathrm{SNC}$ 熱水抽出物 $400 \mathrm{mg} / \mathrm{day}$ (SNC 熱水抽 出プロテオグリカン $169 \mathrm{mg} /$ day) 摂取群の $0 \mathrm{w}$ から $8 \mathrm{w}$ の MTDの増減率は，プラセボ摂取群と比べ有意に上昇した ことから, SNC 熱水抽出物の摂取は, 紫外線によって肌 が黒くなる日焼けを抑制する効果があることが示された。 またこの効果は, 摂取をやめた 8 週間後でも, 持続する傾 向がみられた。 MEDに関しては，群内比較において， $\mathrm{SNC}$ 熱水抽出物 $400 \mathrm{mg} / \mathrm{day}$ 摂取群のみに, $0 \mathrm{w}$ から $16 \mathrm{w}$ に上昇傾向が認められたが，プラセボ摂取群との群間比較 での有意差は認められなかった。紫外線照射後の紅斑は, 炎症反応に密接に関係しているため, SNC 熱水抽出物 400 $\mathrm{mg} / \mathrm{day}$ の摂取により皮膚黒化と同様に紅斑抑制効果もあ るものと考えられるが, 紅斑反応のピークは, 紫外線照射 の 12 時間から 24 時間後であり ${ }^{5}$, その後消失していくた め，照射 1 日後の測定において，ピークになる時間の個人 差がばらつきの要因となり，プラセボ摂取群との有意差が 認められなかった可能性があると推察される。プラセボ摂 取群においても経時的な MED 上昇が見られたが，MED は，夏期で低く，冬期に高くなることが報告されてい る ${ }^{36}$. 本試験期間 (16 週間) は, 10 月 (秋) から 2 月 (冬) であり，MEDの変動は，季節変動の要因が影響したもの と推察された。また, SNC 熱水抽出物 $200 \mathrm{mg} /$ day (SNC 
熱水抽出プロテオグリカン $84 \mathrm{mg} / \mathrm{day})$ の摂取は, MED, MTD のいずれもプラセボと比較して有意な差は認められ なかった

我々は, SNC 脱脂粉末の水抽出液からイオン交換カラ ムクロマトグラフィーに続くゲルろ過カラムクロマトグラ フィーによって精製したプロテオグリカン画分は, 動物レ ベルで皮膚の紅斑発生, 皮膚肥厚などの光老化の抑制効果 が高いことを見出している ${ }^{37)}$. また SNC 熱水抽出物につ いても，イオン交換カラムクロマトグラフィーによりプロ テオグリカンを精製分画し, ゲルろ過カラムクロマトグラ フィーを実施した結果, SNC 脱脂粉末の水抽出と同様の プロテオグリカン分子量分布を示した ${ }^{30)}$. したがって, $\mathrm{SNC}$ 熱水抽出物の摂取による日焼け抑制効果は, SNC 熱 水抽出物に含まれるプロテオグリカンが関与成分であるこ とが示唆された。

SNC 熱水抽出物の日焼け抑制の作用機序としては, $\mathrm{SNC}$ プロテオグリカンによる抗炎症効果が推察される. コンドロイチン硫酸やヒアルロン酸が炎症反応を調節する 作用があることが報告されているが38)，SNCプロテオグリ カンの炎症反応調節についても複数の報告がある。 マウス マクロファージ細胞株 (RAW264.7) 培養系において, 加 熱死菌処理した大腸菌を添加し誘導される TNF- $\alpha$ の産生 に対し， SNCプロテオグリカンは，プロテオグリカンの 糖鎖成分であるコンドロイチン硫酸に比べ強い抑制効果を 有することが報告されている ${ }^{39}$. このことから，コアタン パクに糖鎖 (コンドロイチン硫酸) が結合したプロテオグ リカンの構造が, より抗炎症作用を発揮することが推測さ れた。 ヒト末梢血由来の樹状細胞を用いた研究において, SNC プロテオグリカンがサイトカインの作用を調節する ことにより, 免疫機能に影響を与える可能性も示唆されて いる ${ }^{40)}$. また，デキストラン硫酸ナトリウムの摂取により 誘発した腸炎モデルラットにおいて，SNCプロテオグリ カンの経口投与は，コンドロイチン硫酸の経口投与に比べ て強い炎症抑制効果を示し, 大腸粪便中の総短鎖脂肪酸 量, 特にn-酪酸の量が有意に増加したことから腸内環境 の改善を示す結果であること, 投与されたプロテオグリカ ンは, 消化管内では分解され難いことが示唆されている. そのため, 消化され難いプロテオグリカンの全体構造が腸 内細菌バランスの変化や腸内環境改善による抗炎症効果に 起因していることが推測されている41). さらにIL-10ノッ クアウトマウスの脾臓および腸間膜リンパ節から調製した 細胞浮遊液をマウスに移入して惹起させた腸炎に対して も, SNCプロテオグリカンは, 体重減少や腸管重量の減 少等の症状に対する抑制効果, 脾藏および腸間膜リンパ節 における TNF- $\alpha$, IL-17 などの炎症性サイトカインの産生 に対する抑制効果が報告されている ${ }^{42)}$. 我々は, SNC 脱脂 粉末水抽出物から分画したプロテオグリカンを予め経口投 与させたへアレスマウスに紫外線を照射した後, 血清及び 紫外線照射部位 (背中) の皮膚中の炎症性サイトカインを 測定した. その結果, SNC 脱脂粉末水抽出物から抽出し
たプロテオグリカンは紫外線により誘導された炎症性サイ トカインを抑制することを示した ${ }^{30)}$. 紫外線により誘導さ れた炎症時に発生する様々な炎症性サイトカインがメラニ ン生成を活性化することが報告されており ${ }^{43)}$, 紫外線によ る炎症性サイトカインの抑制が，日焼け (黒化) の抑制に 繋がっているものと推察される. 抗炎症の作用機序とし て，SNCプロテオグリカンは分解され吸収されるのでは なく，プロテオグリカンの構造を保持して腸に留まり，腸 管での免疫系に作用して体質改善的に効果を発揮している ことが推測されている ${ }^{37)}$. 腸管での免疫系に作用して機能 を発揮する成分として, 乳酸菌が挙げられる. 経口摂取さ れた乳酸菌は腸管上皮で認識され, 細胞内シグナル伝達因 子である MAP キナーゼや転写因子である NF-אB などを介 して NK 細胞の活性化, 抗体産生の増強, サイトカイン産 生の制御など様々な作用により, 各種の免疫疾患や炎症性 疾患の予防や治癒に有効であることがわかってきてい る ${ }^{44)}$ ．また姫松咠 (Agaricus blazei Murill) 抽出物は，腸管 上皮の特定のレセプターに結合し，過酸化水素などのメッ センジャーを介して発生した IFN- $\gamma$ がTh1/Th2 バランス に影響を及ぼして，抗アレルギー効果を発揮すると報告さ れている ${ }^{45)}$. 今後, SNC プロテオグリカンの抗炎症作用機 序のさらなる詳細なメカニズムの解明に努めたい.

このように, SNC 熱水抽出物は, 紫外線による日焼け を抑制し，皮膚ダメージを抑制する有益な食品素材であ り，長期的な摂取は，シワやシミなどの光老化を抑制でき るものと考えられる。また日焼けや光老化抑制のみではな く, 炎症に基づく様々な疾患の改善を手助けできる機能性 食品素材として，幅広い分野で今後の高齢化社会における QOLの向上への貢献が期待できる.

\section{謝辞}

本研究に際して，試験に協力していただきました被験者 の皆様, 医療法人健昌会福島健康管理センターの近藤澄夫 医師および DRC 株式会社に深く感謝いたします。

\section{文献}

1 ) G. Jenkins: Molecular mechanisms of skin ageing. Mech. Ageing Dev., 123, 801-810 (2002).

2 ) T. Nose and K. Tsurumi: Pharmacological studies on cutaneous inflammation induced by ultraviolet irradiation (1): Quantification of erythema by reflectance colorimetry and correlation with cutaneous blood flow. Jpn. J. Pharmacol., 62, 245-256 (1993).

3 ) G.J. Clydesdale, G.W. Dandie and H.K. Muller: Ultraviolet light induced injury: immunological and inflammatory effects. Immunol. Cell Biol., 79, 547-568 (2001).

4 ) 正木 仁 : 紫外線の皮膚への作用。フレグランスジャーナ ル, 2004 年 4 月号, 26-33.

5 ) 近藤靖児, 佐藤吉昭：太陽光線と皮膚。「光線過敏症 (第 3 版)」, 佐藤吉昭監修, 金原出版, 東京, pp. 3-17 (2002).

6 ) T. Abe and J. Mayuzumi: The change and recovery of human skin barrier functions after ultraviolet light irradiation. Chem. Pharm. Bull. (Tokyo), 27, 458-462 (1979).

7 ) W.M. Holleran, Y. Uchida, L. Halkier-Sorensen, A. Haratake, M. Hara, J.H. Epstein and P.M. Elias: Structural and biochemical basis for the UVB-induced alterations in epidermal barrier 
function. Photodermatol. Photoimmunol. Photomed., 13, 117128 (1997)

8 ) S.H. Ibbotson, M.N. Moran, J.F. Nash and I.E. Kochevar: The effects of radicals compared with UVB as initiating species for the induction of chronic cutaneous photodamage. J. Invest. Dermatol., 112, 933-938 (1999).

9 ) D.L. Bissett, D.P. Hannon and T.V. Orr: An animal model of solar-aged skin: historogical, physical, and visible changes in UV-irradiated hairless mouse skin. Photochem. Photobiol., 46, 367-378 (1987).

10) S.J. Moloney, S.H. Edmonds, L.D. Giddens and D.B. Learn: The hairless mouse model of photoaging: evaluation of the relationship between dermal elastin, collagen, skin thickness and wrinkles. Photochem. Photobiol., 56, 505-511 (1992).

11）小川文秀, 佐藤伸一：酸化ストレスと皮膚一光老化から全 身性強皮症まで。日臨免誌，29，349-358 (2006).

12) 佐田雅宏, 研谷 啓: 抗シワ・抗老化化粧品の展望. フレ グランスジャーナル，1996 年 1 月号，23-30.

13) 小林静子：紫外線 B 波照射による皮膚障害とその予防・治 療一 $\gamma$-Tocopherol 誘導体塗布の効果一. YAKUGAKU ZASSHI, 126, 677-693 (2006).

14）佐々木政子：太陽紫外線の科学. 日皮会誌，108，15401545 (1998).

15) A.R. Poole: Proteoglycans in health and disease: structures and functions. J. Biol. Chem., 236, 1-14 (1986).

16) H. Watanabe, Y. Yamada and K. Kimata: Roles of aggrecan, a large chondroitin sulfate proteoglycan, in cartilage structure and function. J. Biochem., 124, 687-693 (1998).

17) 前田信明：形態形成を司るプロテオグリカン 組織再生へ の応用を目指して。細胞工学, 20，1074-1083 (2001).

18) T.E. Hardingham and H. Muir: Hyaluronic acid in cartilage and proteoglycan aggregation. Biochem. J., 139, 565-581 (1974).

19) J.A. Buckwalter and L.C. Rosenberg: Electron microscopic studies of cartilage proteoglycans. Direct evidence for the variable length of the chondroitin sulfate-rich region of proteoglycan subunit core protein. J. Biol. Chem., 257, 9830-9839 (1982).

20) M.Mörgelin, M. Paulsson, T.E. Hardingham, D. Heinegård and J. Engel: Cartilage proteoglycans. Assembly with hyaluronate and link protein as studied by electron microscopy. Biochem. J., 253, 175-185 (1988).

21) C. Kiani, L. Chen, Y.J. Wu, A.J. Yee and B.B. Yang: Structure and function of aggrecan. Cell Res., 12, 19-32 (2002).

22) L. Han, D. Dean, L.A. Daher, A.J. Grodzinsky and C. Ortiz: Cartilage aggrecan can undergo self-adhesion. Biophys. J., 95, 4862-4870 (2008)

23) T.E. Hardingham and A.J. Fosang: Proteoglycans: many forms and many functions. FASEB J., 6, 861-870 (1992).

24) I. Kakizaki, Y. Tatara, M. Majima, Y. Kato and M. Endo: Identification of proteoglycan from salmon nasal cartilage. Arch. Biochem. Biophys., 506, 58-65 (2011).

25) I. Kakizaki, T. Mineta, M. Sasaki, Y. Tatara, E. Makino and Y. Kato: Biochemical and atomic force microscopic characterization of salmon nasal cartilage proteoglycan. Carbohydr. Polym., 103, 538-549 (2014).

26) 三浦絢子, 伊藤聖子, 加藤陽治：サケ鼻軟骨粉末から異な る溶媒で抽出したプロテオグリカンの性質の比較。食科工 誌, 60, 237-241 (2013).

27) 国立大学法人弘前大学, 加藤陽治, 伊藤聖子, 工藤重光 : プロテオグリカンの抽出方法, 特許第 5252623 号, 201304-26.
28) I. Kakizaki, A. Miura, S. Ito, T. Mineta, H.J. Seo and Y. Kato: Characterization of proteoglycan and hyaluronan in water-based delipidated powder of salmon cartilage. J. Appl. Glycosci., 62, 115-120 (2015)

29) M. Goto, S. Ito, Y. Kato, S. Yamazaki, K. Yamamoto and Y. Katagata: Anti-aging effects of extracts prepared from salmon nasal cartilage in hairless mice. Mol. Med. Report, 4, 779-784 (2011).

30) Y. Suekawa, M. Goto, K. Yamamoto and Y. Kato: Development of hyaluronic acid-collagen-proteoglycan complex (Hyaluco PG) by hot water extraction from salmon nasal cartilage. J. Appl. Glycosci., 62, 101-106 (2015).

31) T.B. Fitzpatrick: The validity and practicality of sun-reactive skin types I through VI. Arch. Dermatol., 124, 869-871 (1988).

32）上出良一: 紫外線防御の皮膚科学的意義. 粧技誌, $\mathbf{3 0}$, 265-272 (1996).

33) 福井作蔵: 生物化学実験法 1 一還元糖の定量法 (第 2 版). 学会出版センター, 東京, p. 177 (1990).

34) 工藤重光, 伊藤聖子, 吉原秀一, 加藤陽治 : プロテオグリ カンを主成分とするサケ鼻軟骨粉末の安全性評価。食科工 誌, 58, 542-547 (2011).

35) 日本化粧品工業連合会 SPF 専門委員会：日本化粧品工業連 合会 SPF 測定法基準。粧技誌，26，207-214 (1992).

36）中山靖久：紫外・赤外線の皮膚に対する作用効果と安全 性. 照学誌, 61，642-656 (1977)

37) M. Goto, S. Yamazaki, Y. Kato, K. Yamamoto and Y. Katagata: Anti-aging effects of high molecular weight proteoglycan from salmon nasal cartilage in hairless mice. Int. J. Mol. Med., 29, 761-768 (2012).

38) K.R. Taylor and R.L. Gallo: Glycosaminoglycans and their proteoglycans: host-associated molecular patterns for initiation and modulation of inflammation. FASEB J., 20, 9-22 (2006).

39) H. Sashinami, K. Takagaki and A. Nakane: Salmon cartilage proteoglycan modulates cytokine responses to Escherichia coli in mouse macrophages. Biochem. Biophys. Res. Commun., 351, 1005-1010 (2006).

40) H. Yoshino, K, Takahashi, S. Monzen and I. Kashiwakura: Effects of proteoglycan extracted from nasal cartilage of salmon heads on maturation of dendritic cells derived from human peripheral blood monocytes. Biol. Pharm. Bull., 33, 311-315 (2010).

41) S. Ota, S. Yoshihara, K. Ishido, M. Tanaka, K. Takagaki and M. Sasaki: Effects of proteoglycan on dextran sulfate sodiuminduced experimental colitis in rats. Dig. Dis. Sci., 53, 3176$3183(2008)$

42) T. Mitsui, H. Sashinami, F. Sato, H. Kijima, Y. Ishiguro, S. Fukuda, S. Yoshihara, K. Hakamada and A. Nakane: Salmon cartilage proteoglycan suppresses mouse experimental colitis through induction of Foxp3(+) regulatory $\mathrm{T}$ cells. Biochem. Biophys. Res. Commun., 402, 209-215 (2010).

43）今川孝太郎，宮坂宗男：光が皮膚に与える影響，日レ医 誌, 32, 444-451 (2012).

44）加地留美: 乳酸菌の免疫調節作用に関わる細胞内シグナル とその制御, 化学と生物, 50, 182-187 (2012).

45) G. Bouike, Y. Nishitani, H. Shiomi, M. Yoshida, T. Azuma, T. Hashimoto, K. Kanazawa and M. Mizuno: Oral treatment with extract of Agaricus blazei Murill enhanced Th1 response through intestinal epithelial cells and suppressed OVA-sensitized allergy in mice. Evid. Based Complement. Alternat. Med., 2011, 532180 (2011). 